\title{
CORRECTION
}

\section{Publisher Correction: Inflammation-activated CXCL16 pathway contributes to tubulointerstitial injury in mouse diabetic nephropathy}

\author{
Ze-bo Hu${ }^{1}$, Kun-ling $\mathrm{Ma}^{1}$, Yang Zhang ${ }^{1}$, Gui-hua Wang ${ }^{1}$, Liang Liu ${ }^{1}$, Jian Lu ${ }^{1}$, Pei-pei Chen ${ }^{1}$, Chen-Chen Lu ${ }^{1}$ and Bi-cheng Liu ${ }^{1}$
} Acta Pharmacologica Sinica (2019) 40:989-990; https://doi.org/10.1038/s41401-019-0226-8

Correction to: Acta Pharmacol Sin https://doi.org/10.1038/ aps.2017.177, published online 05 April 2018

The REFERENCES 1-35 are wrong because of the error in the process of typesetting.

The technical editor felt very sorry for the mistake.

The correct REFERENCES 1-35 are as follows:

References

1 Gilbert RE, Cooper ME. The tubulointerstitium in progressive diabetic kidney disease: more than an aftermath of glomerular injury. Kidney Int 1999; 56: 1627-37.

2 Tang SC, Lai KN. The pathogenic role of the renal proximal tubular cell in diabetic nephropathy. Nephrol Dial Transplant 2012; 27: 3049-56.

3 Navarro-González JF, Mora-Fernández C, de Fuentes MM, García-Pérez J. Inflammatory molecules and pathways in the pathogenesis of diabetic nephropathy. Nat Rev Nephrol 2011; 7: 327-40.

4 Moriwaki Y, Yamamoto T, Shibutani Y, Aoki E, Tsutsumi Z, Takahashi S, et al. Elevated levels of interleukin-18 and tumor necrosis factor-alpha in serum of patients with type 2 diabetes mellitus: relationship with diabetic nephropathy. Metabolism 2003; 52: 605-8.

5 Navarro JF, Mora C, Muros M, García J. Urinary tumour necrosis factor-alpha excretion independently correlates with clinical markers of glomerular and tubulointerstitial injury in type 2 diabetic patients. Nephrol Dial Transplant 2006; 21: 3428-34.

6 Tarabra E, Giunti S, Barutta F, Salvidio G, Burt D, Deferrari G, et al. Effect of the monocyte chemoattractant protein-1/CC chemokine receptor 2 system on nephrin expression in streptozotocin-treated mice and human cultured podocytes. Diabetes 2009; 58: 2109-18.

7 Wada T, Furuichi K, Sakai N, Iwata Y, Yoshimoto K, Shimizu M, et al. Up-regulation of monocyte chemoattractant protein-1 in tubulointerstitial lesions of human diabetic nephropathy. Kidney Int 2000; 58: 1492-9.

8 Sun L, Halaihel N, Zhang W, Rogers T, Levi M. Role of sterol regulatory element-binding protein 1 in regulation of renal lipid metabolism and glomerulosclerosis in diabetes mellitus. J Biol Chem 2002; 277: 18919-27.

9 Jiang T, Wang XX, Scherzer P, Wilson $\mathrm{P}$, Tallman J, Takahashi $\mathrm{H}_{\text {, }}$ et al. Farnesoid $X$ receptor modulates renal lipid metabolism, fibrosis, and diabetic nephropathy. Diabetes 2007; 56: 2485-93.
10 Shimaoka T, Kume N, Minami M, Hayashida K, Kataoka H, Kita $\mathrm{T}$, et al. Molecular cloning of a novel scavenger receptor for oxidized low density lipoprotein, SR-PSOX, on macrophages. J Biol Chem 2000; 275: 40663-6.

11 Shimaoka T, Nakayama T, Fukumoto N, Kume N, Takahashi S, Yamaguchi J, et al. Cell surface-anchored SRPSOX/CXC chemokine ligand 16 mediates firm adhesion of CXC chemokine receptor 6-expressing cells. J Leukoc Biol 2004; 75: 267-74.

12 Abel S, Hundhausen C, Mentlein R, Schulte A, Berkhout TA, Broadway $\mathrm{N}$, et al. The transmembrane CXC-chemokine ligand 16 is induced by IFN-gamma and TNF-alpha and shed by the activity of the disintegrin-like metalloproteinase ADAM10. J Immunol 2004; 172: 6362-72.

13 Gough PJ, Garton KJ, Wille PT, Rychlewski M, Dempsey PJ, Raines EW. A disintegrin and metalloproteinase 10-mediated cleavage and shedding regulates the cell surface expression of CXC chemokine ligand 16. J Immunol 2004; 172: 3678-85.

14 Gutwein P, Abdel-Bakky MS, Doberstein K, Schramme A, Beckmann J, Schaefer L, et al. CXCL16 and oxLDL are induced in the onset of diabetic nephropathy. J Cell Mol Med 2009; 13: 3809-25.

15 Ruan XZ, Varghese Z, Moorhead JF. An update on the lipid nephrotoxicity hypothesis. Nat Rev Nephrol 2009; 5: 713-21.

$16 \mathrm{Ma} \mathrm{KL}$, Zhang Y, Liu J, Wu Y, Hu ZB, Ruan XZ, et al. Establishment of an inflamed animal model of diabetic nephropathy. Int J Biol Sci 2014; 10: 149-59.

17 Tang SC, Leung JC, Lai KN. Diabetic tubulopathy: an emerging entity. Contrib Nephrol 2011; 170: 124-34.

18 Sanai T, Sobka T, Johnson T, el-Essawy M, Muchaneta-Kubara EC, Ben Gharbia O, et al. Expression of cytoskeletal proteins during the course of experimental diabetic nephropathy. Diabetologia 2000. 43: 91-100.

19 Tang SC, Yiu WH, Lin M, Lai KN. Diabetic nephropathy and proximal tubular damage. J Ren Nutr 2015; 25: 230-3.

20 Esser N, Paquot N, Scheen AJ. Anti-inflammatory agents to treat or prevent type 2 diabetes, metabolic syndrome and cardiovascular disease. Expert Opin Investig Drugs 2015; 24: 283-307.

21 Perry RJ, Camporez JP, Kursawe R, Titchenell PM, Zhang D, Perry $\mathrm{CJ}$, et al. Hepatic acetyl CoA links adipose tissue inflammation to hepatic insulin resistance and type 2 diabetes. Cell 2015; 160: 745-58. 
22 Ginsberg HN. Diabetic dyslipidemia: basic mechanisms underlying the common hypertriglyceridemia and low HDL cholesterol levels. Diabetes 1996; 45 Suppl 3: S27-30.

23 Yamamoto T, Nakamura T, Noble NA, Ruoslahti E, Border WA. Expression of transforming growth factor beta is elevated in human and experimental diabetic nephropathy. Proc Natl Acad Sci USA 1993; 90: 1814-8.

24 Tojo A, Onozato ML, Kurihara H, Sakai T, Goto A, Fujita T. Angiotensin II blockade restores albumin reabsorption in the proximal tubules of diabetic rats. Hypertens Res 2003; 26: 413-9.

25 Kuwabara T, Mori K, Mukoyama M, Kasahara M, Yokoi H, Saito $\mathrm{Y}$, et al. Exacerbation of diabetic nephropathy by hyperlipidaemia is mediated by Toll-like receptor 4 in mice. Diabetologia 2012; 55 : 2256-66.

26 Chen HC, Tan MS, Guh JY, Tsai JH, Lai YL. Native and oxidized low-density lipoproteins enhance superoxide production from diabetic rat glomeruli. Kidney Blood Press Res 2000; 23: 133-7.

27 Ma KL, Ruan XZ, Powis SH, Chen Y, Moorhead JF, Varghese Z. Inflammatory stress exacerbates lipid accumulation in hepatic cells and fatty livers of apolipoprotein E knockout mice. Hepatology 2008; 48: 770-81.

$28 \mathrm{Ma} \mathrm{KL}$, Varghese Z, Ku Y, Powis SH, Chen Y, Moorhead JF, et al. Sirolimus inhibits endogenous cholesterol synthesis induced by inflammatory stress in human vascular smooth muscle cells. Am J Physiol Heart Circ Physiol 2010; 298: H1646-51.
29 Ma KL, Zhang Y, Liu J, Wu Y, Hu ZB, Liu L, et al. Inflammatory stress induces lipid accumulation in multi-organs of $\mathrm{db} / \mathrm{db}$ mice. Acta Biochim Biophys Sin 2015; 47: 767-74.

30 Zhang Y, Ma KL, Liu J, Wu Y, Hu ZB, Liu L, et al. Inflammatory stress exacerbates lipid accumulation and podocyte injuries in diabetic nephropathy. Acta Diabetol 2015; 52: 1045-56.

31 Zhang Y, Ma KL, Liu J, Wu Y, Hu ZB, Liu L, et al. Dysregulation of low-density lipoprotein receptor contributes to podocyte injuries in diabetic nephropathy. Am J Physiol Endocrinol Metab 2015; 308: E1140-8.

32 Liu J, Ma KL, Zhang Y, Wu Y, Hu ZB, Lv LL, et al. Activation of mTORC1 disrupted LDL receptor pathway: a potential new mechanism for the progression of non-alcoholic fatty liver disease. Int J Biochem Cell Biol 2015; 61: 8-19.

33 Ma KL, Liu J, Wang CX, Ni J, Zhang Y, Wu Y, et al. Activation of mTOR modulates SREBP-2 to induce foam cell formation through increased retinoblastoma protein phosphorylation. Cardiovasc Res 2013; 100: 450-60.

34 Ma KL, Ruan XZ, Powis SH, Moorhead JF, Varghese Z. Antiatherosclerotic effects of sirolimus on human vascular smooth muscle cells. Am J Physiol Heart Circ Physiol 2007; 292: H2721-8.

35 Ruan XZ, Moorhead JF, Tao JL, Ma KL, Wheeler DC, Powis SH, et al. Mechanisms of dysregulation of low-density lipoprotein receptor expression in vascular smooth muscle cells by inflammatory cytokines. Arterioscler Thromb Vasc Biol 2006; 26: 1150-5. 